\title{
An Overview on Chemical Constituents, Medicinal Applications, Pharmacological Activity, Toxicology, Metabolism and Pharmacokinetics of Strobilus lupuli
}

\author{
Khaled Mohamed Mohamed Koriem ${ }^{1, * \text { iD }}$ \\ 1 Department of Medical Physiology, Medical Research Division, National Research Centre, 33 El-Buhouth Street, Dokki, \\ Cairo, 12622, Egypt \\ * Correspondence: kkoriem@yahoo.com (K.M.M.K.);
}

Scopus Author ID 24477156100

Received: 14.08.2021; Revised: 25.09.2021; Accepted: 28.09.2021; Published: 16.10.2021

\begin{abstract}
Strobilus lupuli is the dried strobiles (inflorescences) of Humulus lupulus L. (Cannabaceae). Other names of Strobilus lupuli include European hops, hoblon, hop vine, hopfen, and hops. Humulus lupulus L. is an important plant that contains metabolites used in the brewing and pharmaceutical fields. Strobilus lupuli is cultivated in Europe, Asia, and North America, occurring in the world's temperate areas. The analysis of Strobilus lupuli through chromatography analysis showed the presence of bitter substances and xanthohumol. The bitter substances in the resins are the major constituents of Strobilus lupuli, where these substances represent 15-25\% of Strobilus lupuli constituents. Strobilus lupuli is applied as a sedative agent for the treatment of nervous tension and insomnia. Strobilus lupuli is applied in the treatment of dyspepsia and lack of appetite. Strobilus lupuli is applied to treat anemia, bacterial infections, abdominal cramps, dysmenorrhoea, leukorrhoea, dermatitis, diarrhea, migraine, and edema. The pharmacology activity of Strobilus lupuli includes experimental and clinical pharmacology. Experimental pharmacology includes antimicrobial, anti-inflammatory, antioxidant, central nervous system depressant, estrogenic and miscellaneous activities. The oral median lethal dose of ethanol extract of Strobilus lupuli in mice was found to be $500 \mathrm{mg} / \mathrm{kg}$, while the oral median lethal dose of Strobilus lupuli in rats was $2700 \mathrm{mg} / \mathrm{kg}$. No information is available on general precautions or on precautions concerning drug and laboratory test interactions. There is no teratogenic effect in pregnancy, or nursing mothers, or pediatric use of Strobilus lupuli. Strobilus lupuli powder dose $=$ one dose of $0.5 \mathrm{~g}$. Infusion or decoction dose $=0.5 \mathrm{~g} / 150 \mathrm{ml}$ water. Strobilus lupuli extract dose $=0.06$ $0.08 \mathrm{~g}$.
\end{abstract}

Keywords: Strobilus lupuli; Humulus lupulus; Cannabaceae; Medicine; Toxicology; Dose.

(C) 2021 by the authors. This article is an open-access article distributed under the terms and conditions of the Creative Commons Attribution (CC BY) license (https://creativecommons.org/licenses/by/4.0/).

\section{Introduction}

The dried strobiles (inforescences) of Humulus lupulus are called Strobiles lupuli. Humulus lupulus belong to the family Cannabaceae [1,2]. European hops, hachichet addinar, hoblon, hombrecillo, hop vine, hopfen, hops, houblon, houblon grimpant, houblon vulgaire, humulus, lupio, luppulo, lupol, lupulin, lupulo, pijiuha, razak, vidarria, and xianshema are different names of Strobiles lupuli [3-5]. Europe, Asia, and North America are the principal cultivated regions of Strobiles lupuli, which occurred mainly in temperate regions of the world $[5,6]$. Important secondary metabolites are derived from Strobiles lupuli, and these metabolites are used in the brewing and pharmaceutical fields [7]. Strobilus lupuli is a perennial, twining herb (up to $6 \mathrm{~m} \mathrm{high),} \mathrm{and} \mathrm{the} \mathrm{aerial} \mathrm{parts} \mathrm{have} \mathrm{many} \mathrm{long,} \mathrm{angular,} \mathrm{rough-hairy,} \mathrm{entwining}$ 
stems. The growing location of Humulus lupulus had a large effect on its hexyl glucoside levels constituents, while the Humulus lupulus genetic differences affect its levels of linalyl, raspberry ketone, and 2-phenylethyl glucoside constituents [8]. These stems have cordate, palmate, threelobed (5-7 lobed, dark green, stipulate leaves). The flowers have 5 bracts and 5 stamens. These flowers are pale green with an entire cup-like perianth and unilocular ovary. The fruits are ovate to ovate-cylindrical strobiles with flexuous rachis. These fruits are yellowish-green to pale brown, ovate, and scaly bracts. The fruits contain brown glandular achene [6]. Strobilus lupuli is ovoid-cylindrical or cone-like. It is leafy ( $3-4 \mathrm{~cm}$ long and up to $3 \mathrm{~cm}$ wide). It contains a narrow, hairy, flexuous rachis and many imbricated, yellowish-green to dusky yellow, obliquely ovate, membranous bracts. It has orange to yellowish-orange glandular trichomes. It has light brown achene [6]. Strobilus lupuli odor is strong and aromatic, while its taste is aromatic and bitter [6]. Strobilus lupuli powder is greenish-yellow in color. [2]. There are 3 types of Humulus lupulus called Cascade, Chinook, and Nuggett are suitable to be cultivated in semi-arid Mediterranean environments [9]. Phytocystatin (Hop1) is extracted from Humulus lupulus. The expression of Hop1 in plants increases resistance to herbivory by insects and improves tolerance to both biotic and abiotic stress factors [10]. Humulus lupulus essential oil, as well as, Humulus lupulus constituents ( $\beta$-myrcene, $\alpha$-humulene, and $\beta$-caryophyllene) possesses control against Sitophilus granaries insect [11]. Humulus lupulus showed an increase in flavanols constituents which refers to Humulus lupulus role to prevent fungus from spread into the Humulus lupulus stem [12]. Humulus lupulus shoots well-maintained their nutrients than leaves, and this effect correlated with different tissue structures. Fresh Humulus lupulus contains high fiber constituents, which and remain after Humulus lupulus cooking. Humulus lupulus ingredients such as magnesium, potassium, sodium, and zinc declined by $50 \%$ due to cooking, while calcium, copper, iron, and manganese were more stable [13].

The aim of this review is to focus on chemical constituents, medicinal uses, pharmacological activity, metabolism, and pharmacokinetics of Strobilus lupuli.

\section{Chemical Constituents of Strobilus lupuli}

The analysis of Strobilus lupuli by chromatography analysis showed the presence of bitter substances and xanthohumol [3]. There are high quantities of $\beta$-caryophyllene, humulene, linalool, and geraniol content and low quantities of myrcene content of Strobilus lupuli during the period of its storage [14]. The bitter acids of Humulus lupulus improve beer quality. Bitter acids and xanthohumol constituents of Humulus lupulus have a beneficial effect on human health [15]. Humulus lupulus contains volatile aroma compounds, and it presents as free volatiles and bound glycosides [16]. Humulus lupulus contains a new polysaccharide called HLP50-1 (molecular weight = 49.13 kiloDalton), where HLP50-1 has an osteogenic effect, and it is used to treat osteoporosis [17]. Humulus lupulus L. has volatile compounds such as aromas constituents. There are many aromas, such as lupulone (the main component) and humulone component [18]. Humulus lupulus L. contains $\alpha$-acids and $\beta$-acids (humulones and lupulones). Also, Humulus lupulus L. has volatile caryophyllene, humulene and $\beta$-myrcene constituents. These compounds were extracted by chromatography associated with spectrometry analysis. This technique increases $\beta$-acids (20\%), $\alpha$-acids (20\%), humulene (5.6\%), and caryophyllene (7.4\%) [19]. 


\section{Major Chemical Constituents of Strobilus lupuli}

The bitter substances in the resins are the major constituents of Strobilus lupuli, where these substances represent 15-25\% of Strobilus lupuli constituents. The resins are 2 forms; (1) hard (petroleum-ether insoluble) and (2) soft resins. The soft resins contain; (1) $\alpha$-acids (such as $\alpha$-humulene (2,6,9-humulatriene) and related humulones) and (2) $\beta$-acids (lupulones). The soft resins' major chemical constituents are humulone and lupulone and their related derivatives, $2-10 \%$, and $2-6 \%$, respectively. The hard resins contain $\delta$-resin and $\gamma$-resin. The Strobilus lupuli contains essential oil (0.3-1.0\%) such as $\beta$-caryophyllene, farnesene, humulene and $\beta$-myrcene $[3,5,20,21]$. The essential oil has traces of 2-methylbut-3-ene-2-ol, which increases to a maximum of $0.15 \%$ after storage of Strobilus lupuli for 2 years (due to hydrolysis of humulones and lupulones). Strobilus lupuli also includes the chalcone xanthohumol, prenylflavonoids, and other flavonoids (such as kaempferol, rutin) and tannins [3, 22, 23]. Humulus lupulus contains many flavonoids such as robinin, nicotiflorin, astragalin, kaempferol-7- $O$-rutinoside, hyperin, rutin, quercetin-7- $O$-rutinoside, and manghaslin [24].

\section{Strobilus lupuli Medicinal Uses}

Strobilus lupuli is applied as a sedative agent for the treatment of nervous tension and insomnia. Strobilus lupuli is applied to treat dyspepsia and lack of appetite [5, 25-27]. Humulus lupulus L. extract protects against bone loss and can potentially treat osteoporosis in osteoporosis mice [28]. Humulus lupulus showed an anti-psoriatic effect by inhibiting the expression of $\beta$-defensin 2, keratin 17, and glucose transporter 1. Also, Humulus lupulus has anti-proliferative and anti-inflammatory effects [29]. Xanthohumol (a prenylated flavonoid isolated from Humulus lupulus L.) attenuates cardiac dysfunction, hypertrophy, and fibrosis, therefore, has xanthohumol cardiovascular protective effect [30]. Humulus Lupulus L. suppressed interleukin-6 mRNA expression to $32 \%$ and to $61 \%$ at a protein level. Humulus Lupulus reduced cyclooxygenase- 2 mRNA expression to $47 \%$ and their protein expression to $32 \%$. Humulus Lupulus decreased inducible nitric oxide synthase protein expression to $2 \%$ and nitric oxide production. Humulus Lupulus declined nuclear factor- $\kappa \mathrm{B}$. Both mRNA and protein expression of nuclear factor- $\mathrm{kB}$ was decreased to $38 \%$ and $42 \%$, respectively. Therefore Humulus Lupulus decreases the expression of inflammatory factors, so Humulus Lupulus has an anti-inflammatory effect [31]. Humulus Lupulus ameliorated fine dust-induced vascular dysfunction. Also, xanthohumol and isoxanthohumol constituents of Humulus Lupulus were found to produce the same protective effect of Humulus Lupulus in cardiovascular dysfunction. Therefore Humulus Lupulus and its active components possess therapeutic effect to prevent or treat air-pollution-associated cardiovascular diseases [32].

\section{Strobilus lupuli in Traditional Medicine}

Strobilus lupuli is applied to treat anemia, bacterial infections, abdominal cramps, dysmenorrhoea, leukorrhoea, dermatitis, diarrhea, migraine, and edema [5,6]. In traditional medicine, humulus japonicus exhibits anti-inflammatory, antimicrobial, and anti-tumor effects used to treat hypertension, pulmonary disease, and leprosy. It demonstrates a neuroprotective effect in animal models of neurodegenerative diseases [33]. Xanthohumol constituent of Strobilus lupuli is applied as an anticarcinogenic, antidiabetic, antimicrobial, and antiinflammatory agent. Xanthohumol is used to treat autism, bone osteoporosis, skin, microbial, lipid-related diseases. Xanthohumol inhibits inflammatory mediators in cardiovascular disease, 
neurodegeneration, and tumors. Xanthohumol decreases adipogenesis and controls obesity by focusing on adipocyte proteins. Xanthohumol is used as a flavoring agent in beer manufacture [34]. Strobilus lupuli is applied as antipyretic, analgesic, anthelmintic, aphrodisiac, carminative, depurative, digestant, diuretic, diaphoretic, and diaphoretic tonic [5,6]. Humulus Lupulus is used to prevent and heal several prevalent diseases such as cardiovascular disorders and many cancer types due to its antimicrobial, antioxidative, and antigenotoxic activities [35].

\section{Pharmacology Activity of Strobilus lupuli}

\subsection{Experimental pharmacology.}

\subsubsection{Antimicrobial activity.}

Humulus lupulus extract ( $5 \mathrm{mg} / \mathrm{L})$ possesses antimicrobial activity [36]. Humulus lupulus extract has an antibacterial effect in Gram-positive bacteria strains [37]. Humulus lupulus extract showed a good antimicrobial action [38]. Strobilus lupuli (2.5 $\mu 1 /$ disc) inhibited the growth of Bacillus subtilis, Trichophyton interdigitale, Staphylococcus aureus, Candida albicans, and Escherichia coli [39]. Strobilus lupuli possessed antimicrobial effects against Gram-positive bacteria (Bacillus subtilis and Staphylococcus aureus) and Trichophyton mentagrophytes var. interdigitale but no activity against a Gram-negative bacterium (Escherichia coli) or the yeast Candida albicans [40]. Strobilus lupuli declined the growth of Helicobacter pylori, and the effective dose $=63-130 \mu \mathrm{g} / \mathrm{ml}$ [41]. Strobilus lupuli and its lupulone constituent inhibited the growth of Mycobacterium tuberculosis, and the effective dose $=1-10 \mu \mathrm{g} / \mathrm{ml}$ for lupulone and $7.5 \mu \mathrm{g} / \mathrm{ml}$ for the decoction [42]. The antibacterial effect of Strobilus lupuli is inversely related to $\mathrm{pH}$ of the medium. Where Strobilus lupuli against Lactobacillus brevis IFO 3960 at a $\mathrm{pH}=4-7$ declined the bacterial growth [43].

\subsubsection{Anti-inflammatory activity.}

Strobilus lupuli applied to mouse ears ( $2 \mathrm{mg} / \mathrm{ear})$ stopped 12-O-tetradecanoylphorbol13-acetate-induced inflammation by $90 \%$ [44]. Humulone constituent of Strobilus lupuli (1 $\mathrm{mg} /$ animal) declined ear inflammation caused by $12-O$-tetradecanoylphorbol-13-acetate and ear edema caused by arachidonic acid in mice [45]. $\beta$-acids or lupulones constituent of Humulus lupulus possesses anti-inflammatory as well as anti-cancer, antioxidative, and antimicrobial activity [46]. Humulus lupulus extract anti-inflammatory as well as antioxidant and antibacterial effects; therefore, Humulus lupulus is used to treat acne-prone skin [47].

\subsubsection{Antioxidant activity.}

Strobilus lupuli had antioxidant and radical scavenging activities in vitro [48, 49]. Humulus lupulus has higher quantities of $\alpha$-bitter acids and $\beta$-bitter acids (522.8 and 345.0 $\mathrm{mg} / \mathrm{g}$ extract, respectively) and volatiles such as $\beta$-humulene, $\beta$-myrcene, $\beta$-pinene, $\alpha$ humulene, $\alpha$-selinene, and methyl-4-decenoate, which have antioxidant activities [50]. Humulus lupulus has bitter acids, oils, and flavonoids (antioxidants and immunity stimulators [51]. Humulus lupulus contains many compounds with antioxidant effects such as phenolic, polyphenolic, $\alpha$-acids, and $\beta$-acids constituents [52]. Humulus lupulus ethanol extract showed higher antioxidative activities than Humulus lupulus water extract [53]. Xanthohumol is the main constituent of Humulus lupulus, and these constituents have antioxidant, antiinflammatory, immunity oppressive, and chemoprotective properties. The concentrations of 
xanthohumol of Humulus lupulus in flowers and food complements ranged between 0.106 and $12.7 \mathrm{mg} / \mathrm{g}$ [54].

\subsubsection{Central nervous system depressant activity.}

Humulus lupulus contains neuroactive compounds that are useful in traditional medicine as a sleeping aid. Humulone ( $\alpha$-acid) and 6-prenylnaringenin (prenylflavonoid) are the most active neuroactive compounds of Humulus lupulus. Both humulone and 6prenylnaringenin act principally on the $\gamma$-aminobutyric acid (GABA) site [55]. Neither Humulus lupulus extract nor its alpha-acid constituent impacts the locomotor effect. Also, Humulus lupulus extract or its alpha-acid constituent has an anxiolytic effect [56]. Humulus lupulus extract reduced immobility during the behavioral despair test when administered 3 times [56]. Humulus lupulus extract exerts: (a) a pentobarbital sleep-enhancing property without influencing the motor behavior of rats; (b) an antidepressant activity. The same effects were elicited by administering Humulus lupulus fraction containing $\alpha$-acids, which can be considered the major responsible for the enhanced pentobarbital effect and the antidepressant effect [56]. Humulus lupulus (i.p., $0.80 \mathrm{~g} / \mathrm{kg}$ ) to mice produced narcosis for about $8 \mathrm{~h}$; no abnormal behavior was observed there. This effect was related to the volatile fraction of Humulus lupulus [57]. The sedative effect of Humulus lupulus was dependent on its 2-methyl3-butene-2-ol ingredient. There were only traces of this compound was detected in hops (their concentration increased to maximum $(0.15 \%)$ after drying for 2 years at room temperature [58]. The sedative effect of Humulus lupulus is similar in its effect to Cupressus sempervirens in its effect [59]. Strobilus lupuli $(\leq 2 \mu \mathrm{g} / \mathrm{ml})$ bound to the $\gamma$-aminobutyric acid and the $N$-methyl-dasparate receptors, as well as the chloride ion channel and glycine receptors in vitro [60]. Xanthohumol constituent of Humulus lupulus L. reduced the latency and increased the residence time of mice. Xanthohumol increased superoxide dismutase levels and reduced Interleukin- 6 and Interleukin- $1 \beta$ levels both in the serum and hippocampus. Xanthohumol also activated autophagy and anti-apoptotic signals. Therefore, xanthohumol ameliorates memory impairment, and consequently, it has a neuroprotective effect [61].

\subsubsection{Estrogenic activity.}

Humulus lupulus L. has phytoestrogen such as 8-prenylnaringenin, 6prenylanaringenin, 6,8-diprenylnaringenin, and 8-geranylnaringenin are fundamental for the active estrogen activity of Humulus lupulus L. [62]. Older women tend to take Humulus lupulus as natural alternatives to relieve menopausal symptoms. Humulus lupulus is enriched in bioactive prenylated flavonoids such as 8-prenylnaringenin, isoxanthohumol, xanthohumol, and 6-prenylnaringenin. 8-prenylnaringenin is one of the most potent phytoestrogens and is responsible for Humulus lupulus estrogenic activity [63]. Humulus lupulus contains an active estrogen compound (flavanone prenylnaringenin), and its extraction was done by thin-layer chromatography-mass spectrometry [64]. Injection of water or ethanol extract of Strobilus lupuli has an estrogenic effect in mice and rats $[65,66]$. The ethanol extract of Strobilus lupuli was greater than that of water extract of $17-\beta$-estradiol equivalents $(1250 \mu \mathrm{g} / \mathrm{g}$ compared with 30-300 $\mu \mathrm{g} / \mathrm{g}$ ) [65]. In other researches, no estrogenic effect in mice occurred after injection of Strobilus lupuli doses (up to $51 \mathrm{mg} / \mathrm{kg}$ ) [67]. Injecting $5 \mathrm{mg}$ of alcohol extract of Strobilus lupuli to rats had a luteal suppressant effect [68]. Strobilus lupuli increased alkaline phosphatase activity in human endometrial cells, Ishikawa variety I in vitro [69]. Methanol 
extract of Strobilus lupuli bound to estrogen receptor- $\alpha$ and receptor- $\beta$ from rat uteri [70]. Methanol extract of Strobilus lupuli also induced the expression of alkaline phosphatase activity and upregulated progesterone receptor messenger RNA [70]. Humulus lupulus contains active estrogenic compounds such as 6-prenylnaringenin and 8-prenylnaringenin. 8prenylnaringenin is more bioavailable in healthy humans than its isomer 6-prenylnaringenin. 6-prenylnaringenin is similarly effective as 8-prenylnaringenin in enhancing peripheral blood viability [71]. 8-prenylnaringenin is used for the treatment of menopausal and post-menopausal symptoms in women. 8-prenylnaringenin prevents bone osteoporosis and tumor development [72].

\subsubsection{Miscellaneous activity.}

Injection of 3 doses of Strobilus lupuli $(30 \mathrm{mg} / \mathrm{animal}$ ) stimulated glutathione-Stransferase activity in the liver and intestine of mice [73]. The flavonoids isolated from Strobilus lupuli (0.1-100 $\mu \mathrm{mol} / \mathrm{l})$ stopped the growth of human breast cancer, colon cancer, and ovarian cancer cells in in-vitro studies [74]. In addition, the flavonoids isolated from Strobilus lupuli (isoxanthohumol, xanthohumol, and 8-prenylnaringenin) at dose $=10 \mu \mathrm{mol} / \mathrm{L}$ declined the 7-ethoxyresorufi n- $O$-dethylase activity of cytochrome P450 [75].

\subsection{Clinical pharmacology.}

Humulus lupulus L. has beneficial effects by normalizing weight, lipid, glucose, insulin, and inflammation by affecting many organs. Humulus lupulus exerts its role due to the bitter acid constituent of Humulus lupulus in preventing metabolic-related diseases such as diabetes, dyslipidemia, and inflammation [76]. Humulus japonicas increased the chondrocytes and growth plate height during the bone growth process [77]. Xanthohumol (a prenylated flavonoid extracted for Humulus lupulus L) amended clinical symptoms, lung physiology, and inflammation in pig lung tissue infected by porcine viral infection. Therefore xanthohumol is a good factor to treat porcine respiratory viral infections [78]. Xanthohumol inhibits phosphorylation of protein kinase B and nuclear factor kappa-B, decreases blood glucose, and increases body weight. Also, xanthohumol increased freezing time, synaptic plasticity, and dendritic spine density while decreasing oxidative stress in the hippocampus area of diabetic rats. Therefore, xanthohumol is a promising agent to treat diabetic encephalopathy [79].

\section{Metabolism and Pharmacokinetics of Strobilus lupuli}

Regarding metabolization of Humulus lupulus $\alpha$ - and $\beta$-acids, there are 33 compounds detected, including novel metabolites (such as 9 potential oxidized metabolites of humulones, and 10 glucuronide conjugates of $\alpha$-acids, comprising 7 glucuronide derivatives of oxidized phase I metabolites) [80]. There are 14 compounds that increased or decreased in response to drought stress. A total of 10 of these compounds were identified as follows: 5 glycerolipids (glutaric acid, pheophorbide A, abscisic acid, roseoside, and dihydromyricetin). Some of the metabolite changes occur across all plants under drought conditions, while others may be specific to Humulus lupulus or the type of drought [81]. Humulus lupulus-derived compounds (cis-isocohumulone, trans-isocohumulone, cis-isohumulone, trans-isohumulone, cisisoadhumulone, trans-isoadhumulone, humulone, cohumulone, adhumulone, and 8prenylnaringenin) are bioactive compounds and are considered as compounds for drug discovery to treat metabolic diseases [82]. Humulus lupulus dietary supplement (xanthohumol 
and 8-prenylnaringenin) caused no clinically relevant pharmacokinetic interactions. The serum obtained after the consumption of Humulus lupulus extract revealed abundant Phase II conjugates of Humulus lupulus prenylated phenols were observed, including monoglucuronides, monosulfates, diglucuronides, and sulfate-glucuronic acid diconjugates [83]. Humulus lupulus contains phytoestrogen precursors, which transform into estrogenic forms in the gut. Humulus lupulus extract decreased visceral lipids and liver triglyceride in ovariectomized animals [84]. Humulus japonicus increased the expression of brown adipose markers. It induced fatty acid oxidation and lipolysis and suppressed both lipogenic markers and lipid accumulation. Humulus japonicus ameliorated oxidative stress [85]. The increased fatty acid oxidation and lipolysis of Humulus lupulus play an important role in decreasing lipids [86] and protecting from infectious diseases [87]. Humulus lupulus caused increases in the pathogenic Enterobacteriaceae and Akkermansia of human gut bacterial communities. Thus, Humulus lupulus had a significant impact on bacterial consortium [88].

\section{Toxicology of Strobilus lupuli}

The median lethal dose (LD50) of an oral dose of ethanol extract of Strobilus lupuli in mice was found to be $500 \mathrm{mg} / \mathrm{kg}$ [57]. The oral LD 50 of Strobilus lupuli in rats was $2700 \mathrm{mg} / \mathrm{kg}$ [57]. The oral $\mathrm{LD}_{50}$ for lupulone constituent of Strobilus lupuli was $525 \mathrm{mg} / \mathrm{kg}$ in mice and $1800 \mathrm{mg} / \mathrm{kg}$ in rats [3]. The injection $\mathrm{LD}_{50}$ of an ethanol extract of Strobilus lupuli in mice was $175 \mathrm{mg} / \mathrm{kg}$ [27].

\section{Adverse Reactions of Strobilus lupuli}

Contact dermatitis is an adverse effect of Humulus lupulus [89]. Contact urticarial is related to Humulus lupulus, while rhinitis, conjunctivitis, asthma are rare [90].

\section{Contraindications of Strobilus lupuli}

Strobilus lupuli is contraindicated in cases of known allergy to the plant material.

\section{Precautions of Strobilus lupuli}

\subsection{Drug interactions}

No drug interactions have been reported. The flavonoid constituents of Strobilus lupuli inhibit the activity of cytochrome P450, and concurrent administration of Strobilus lupuli may influence the pharmacokinetics of some drugs.

\subsection{Carcinogenesis, mutagenesis, impairment of fertility.}

Xanthohumol inhibits free radicals and cell proliferation while increasing apoptosis. Therefore, it is used as a chemoprotective/therapeutic agent in colorectal cancer [91]. The antitumor effect of Humulus lupulus plays an important role in colon cancer protection [92]. Injection of $20-50 \mathrm{mg} / \mathrm{kg}$ of Strobilus lupuli twice daily for 3 days to female rats pretreated by injection with 25 IU (international unit) of pregnant mare's serum gonadotrophin did not induce any changes in uterine weight, but ovarian weight decreased significantly [93]. Xanthohumol has a chemoprotective effect against the carcinogenic food contaminant aflatoxin B1 [94]. Xanthohumol treats microbial infection, aging, inflammation, diabetes, and cancer. 
Xanthohumol has a therapeutic effect against many tumors, and it is used as an anti-cancer agent with minimal adverse effects [95].

\subsection{Other precautions.}

No information is available on general precautions or precautions concerning drug and laboratory test interactions. There is no teratogenic effect in pregnancy, or nursing mothers, or pediatric use.

\section{Dosage of Strobilus lupuli}

Strobilus lupuli has many forms, such as dry strobiles, dry extracts, fluidextracts, and tinctures [6, 26]. Strobilus lupuli must store in a container away from light and humidity. In Strobilus lupuli powder for decoctions, infusion, and other preparations (=one dose of $0.5 \mathrm{~g}$ ). An infusion or decoction $(=0.5 \mathrm{~g}$ in $150 \mathrm{ml}$ of water). In fluidextract $1: 1(\mathrm{~g} / \mathrm{ml})=0.5 \mathrm{ml}$. In tincture 1:5 $(\mathrm{g} / \mathrm{ml})=2.5 \mathrm{ml}$. In Strobilus lupuli extract 6-8:1 $(\mathrm{w} / \mathrm{w})=0.06-0.08 \mathrm{~g}$ [26].

\section{Conclusions}

Dried strobiles (inflorescences) of Humulus lupulus are called Strobilus lupuli. Humulus lupulus occurs in the family Cannabaceae. Europe, Asia, and North America are the principal cultivated areas of Humulus lupulus. The most famous names of Strobilus lupuli are European hops, hoblon, hop vine, hopfen, and hops. The chemical constituents of Strobilus lupuli are bitter substances and xanthohumol. Bitter substances are the main constituents (15$25 \%$ of Strobilus lupuli constituents). Strobilus lupuli is used as a sedative agent in folk medicine to treat both nervous disturbances and insomnia. Strobilus lupuli is also used to treat dyspepsia and lack of appetite. In medical applications, strobilus lupuli treats anemia, bacterial infections, abdominal cramps, dysmenorrhoea, leukorrhoea, dermatitis, diarrhea, migraine, and edema. Strobilus lupuli has experimental pharmacology and clinical pharmacology. Strobilus lupuli ethanol extracts lethal doses in mice and rats are $500 \mathrm{mg} / \mathrm{kg}$ and $2700 \mathrm{mg} / \mathrm{kg}$, respectively. Strobilus lupuli occurs in many forms such as powder, infusion, decoction, and extract, and the Strobilus lupuli doses are one dose of $0.5 \mathrm{~g}$ (as a powder), $0.5 \mathrm{~g} / 150 \mathrm{ml}$ water (as an infusion or decoction), and 0.06-0.08 $\mathrm{g}$ (as an extract).

\section{Funding}

This review received no external funding.

\section{Acknowledgments}

This research has no acknowledgment.

\section{Conflicts of Interest}

The author declares no conflict of interest.

\section{References}

1. British herbal pharmacopoeia. Exeter, British Herbal Medicine Association, 1996.

2. European pharmacopoeia, 3rd ed. Suppl. 2001. Strasbourg, Council of Europe, 2001. 
3. Hansel, R.; Keller, K.; Rimpler, H.; Schneider, G. eds. Hagers Handbuch der pharmazeutischen Praxis. Bd 5,Drogen E-O, 5th ed. [Hager's handbook of pharmaceutical practice. Vol. 5, Drugs E-O, 5th ed.] Berlin, Springer, 1993.

4. Drogenkunde, Band 1: Angiospermen, von H. A. Hoppe, VIII, 1311 S., Preis DM 325, Verlag Walter de Gruyter, Berlin, New York 1975, Arch Pharm 1976, 309, 76, https://doi.org/10.1002/ardp.19763090118.

5. Bisset, N.G. Herbal drugs and phytopharmaceuticals. Boca Raton, FL, CRC Press, 1994.

6. Youngken, H.W. Textbook of pharmacognosy, 6th ed. Philadelphia, PA, Blakiston, 1950.

7. Awasthi, P.; Kocábek, T.; Mishra, A.K.; Nath, V.S.; Shrestha, A.; Matoušek, J. Establishment of CRISPR/Cas9 mediated targeted mutagenesis in Hop (Humulus lupulus). Plant Physiol Biochem 2021, 160, 1-7, https://doi.org/10.1016/j.plaphy.2021.01.006.

8. Morcol, T.B.; Negrin, A.; Matthews, P.D.; Kennelly, E.J. Hop (Humulus lupulus L.) terroir has large effect on a glycosylated green leaf volatile but not on other aroma glycosides. Food Chem 2020, 321, 126644, https://doi.org/10.1016/j.foodchem.2020.126644.

9. Marceddu, R.; Carrubba, A.; Sarno, M. Cultivation trials of hop (Humulus lupulus L.) in semi-arid environments. Heliyon 2020, 6, e05114, https://doi.org/10.1016/j.heliyon.2020.e05114.

10. Moura, G.T.; Souza, A.A.; Garay, A.V.; Freitas, S.M.; Valadares, N.F. Crystal structure and physicochemical characterization of a phytocystatin from Humulus lupulus: Insights into its domain-swapped dimer. Biochim Biophys Acta Proteins Proteom 2021, 1869, 140541, https://doi.org/10.1016/j.bbapap.2020.140541.

11. Paventi, G.; de Acutis, L.; De Cristofaro, A.; Pistillo, M.; Germinara, G.S.; Rotundo, G. Biological activity of Humulus lupulus (L.) essential oil and its main components against Sitophilus granarius (L.). Biomolecules 2020, 10, 1108, https://doi.org/10.3390/biom10081108.

12. Kunej, U.; Mikulič-Petkovšek, M.; Radišek, S.; Štajner, N. Changes in the phenolic compounds of Hop (Humulus lupulus L.) induced by infection with verticillium nonalfalfae, the causal agent of Hop verticillium wilt. Plants (Basel) 2020, 9, 841, https://doi.org/10.3390/plants9070841.

13. García-Herrera, P.; Morales, P.; Cámara, M.; Fernández-Ruiz, V.; Tardío, J.; Sánchez-Mata, M.C. Nutritional and phytochemical composition of mediterranean wild vegetables after culinary treatment. Foods 2020, 9 , 1761, https://doi.org/10.3390/foods9121761.

14. Raut, S.; von Gersdorff, G.J.; Münsterer, J.; Kammhuber, K.; Hensel, O.; Sturm, B. Influence of pre-drying storage time on essential oil components in dried hops (Humulus lupulus L.). J Sci Food Agric 2021, 101, 2247-2255, https://doi.org/10.1002/jsfa.10844.

15. Iniguez, A.B.; Zhu, M.J. Hop bioactive compounds in prevention of nutrition-related non-communicable diseases. Crit Rev Food Sci Nutr 2021, 61, 1900-1913, https://doi.org/10.1080/10408398.2020.1767537.

16. Caffrey, A.; Ebeler, S.E. The occurrence of glycosylated aroma precursors in Vitis vinifera fruit and Humulus lupulus hop cones and their roles in wine and beer volatile aroma production. Foods 2021, 10, 935, https://doi.org/10.3390/foods10050935.

17. Chen, X.; Li, T.; Qing, D.; Chen, J.; Zhang, Q.; Yan, C . Structural characterization and osteogenic bioactivities of a novel Humulus lupulus polysaccharide. Food Funct 2020, 11, 1165-1175, https://doi.org/10.1039/c9fo01918a.

18. Rapinel, V.; Chemat, A.; Santerre, C.; Belay, J.; Hanaei, F.; Vallet, N.; Jacques, L.; Fabiano-Tixier, A.S. 2Methyloxolane as a bio-based solvent for green extraction of aromas from hops (Humulus lupulus L.). Molecules 2020, 25, 1727, https://doi.org/10.3390/molecules25071727.

19. Ntourtoglou, G.; Tsapou, E.A.; Drosou, F.; Bozinou, E.; Lalas, S.; Tataridis, P.; Dourtoglou, V. Pulsed electric field extraction of alpha and beta-acids from pellets of Humulus lupulus (hop). Front Bioeng Biotechnol 2020, 8, 297, https://doi.org/10.3389/fbioe.2020.00297.

20. Bradley, PR. ed. British herbal compendium. Vol. 1. Bournemouth, British Herbal Medicine Association, 1992.

21. Bruneton, J. Pharmacognosy, phytochemistry, medicinal plants. Paris, Lavoisier, 1995.

22. Holzl, J. Inhaltsstoffe des Hopfens (Humulus lupulus L.). [Constituents of hops (Humulus lupulus L.).]. Zeitschrift für Phytotherapie 1992, 13,155-161.

23. Stevens, J.F.; Ivancic, M.; Hsu, V.L.; Deinzer, M.L. Prenylfl avonoids from Humulus lupulus. Phytochemistry 1997, 44, 1575-1585, https://doi.org/10.1016/S0031-9422(96)00744-3.

24. da Silva, R.G.; Almeida, T.C.; Reis, A.C.C.; Filho, S.A.V.; Brandão, G.C.; da Silva, G.N.; de Sousa, H.C.; de Almeida, V.L.; Lopes, J.C.D.; de Souza, G.H.B. In silico pharmacological prediction and cytotoxicity of flavonoids glycosides identified by UPLC-DAD-ESI-MS/MS in extracts of Humulus lupulus leaves cultivated in Brazil. Nat Prod Res 2020, https://doi.org/0.1080/14786419.2020.1803308. 
25. Chang, H.M.; But, P.P.H. Pharmacology and applications of Chinese material medica. Vol. II. Singapore, World Scientific, 1987.

26. Blumenthal, M.; Busse, W.R. Goldberg A, Gruenwald J, Hall T, Riggins CW, eds. The complete German commission E monographs: Therapeutic guide to herbal medicines. Austin, TX: American Botanical Council, 1998.

27. Kee, C.H. The pharmacology of Chinese herbs, 2nd ed. Boca Raton, FL, CRC Press, 1999.

28. Xia, T.S.; Lin, L.Y.; Zhang, Q.Y.; Jiang, Y.P.; Li, C.H.; Liu, X.Y.; Qin, L.P.; Xin, H.L. Humulus lupulus L. extract prevents ovariectomy-induced osteoporosis in mice and regulates activities of osteoblasts and osteoclasts. Chin J Integr Med 2021, 27, 31-38, https://doi.org/10.1007/s11655-019-2700-z.

29. Gendrisch, F.; Haarhaus, B.; Krieger, N.; Quirin, K.W.; Schempp, C.M.; Wölfle, U. The effect of herbal medicinal products on psoriasis-like keratinocytes. Biomolecules 2021, 11, 371, https://doi.org/10.3390/biom11030371.

30. Sun, T.L.; Li, W.Q.; Tong, X.L.; Liu, X.Y.; Zhou, W.H. Xanthohumol attenuates isoprenaline-induced cardiac hypertrophy and fibrosis through regulating PTEN/AKT/mTOR pathway. Eur J Pharmacol 2021, 891,173690, https://doi.org/10.1016/j.ejphar.2020.173690.

31. Caban, M.; Chojnacka, K.; Owczarek, K.; Laskowska, J.; Fichna, J.; Podsedek, A.; Sosnowska, D.; Lewandowska, U. Spent hops (Humulus Lupulus L.) extract as modulator of the inflammatory response in lipopolysaccharide stimulated RAW 264.7 macrophages. J Physiol Pharmacol 2020, 71, 67-78, https://doi.org/10.26402/jpp.2020.1.05.

32. Shiwakoti, S.; Adhikari, D.; Lee, J.P.; Kang, K.W.; Lee, I.S.; Kim, H.J.; Oak, M.H. Prevention of fine dustinduced vascular senescence by Humulus lupulus extract and its major bioactive compounds. Antioxidants (Basel) 2020, 9, 1243, https://doi.org/10.3390/antiox9121243.

33. Park, H.Y.; Go, J.; Ryu, Y.K.; Choi, D.H.; Noh, J.R.; An, J.P.; Oh, W.K.; Han, P.L.; Lee, C.H.; Kim, K.S. Humulus japonicus rescues autistic-like behaviours in the BTBR T(+) Itpr3(tf)/J mouse model of autism. Mol Med Rep 2021, 23, 448, https://doi.org/10.3892/mmr.2021.12087.

34. Aggarwal, D.; Upadhyay, S.K.; Singh, R.; Tuli, H.S. Recent patents on therapeutic activities of xanthohumol: a prenylated chalconoid from hops (Humulus lupulus L.). Pharm Pat Anal 2021, 10, 37-49, https://doi.org/10.4155/ppa-2020-0026.

35. Knez Hrnčič, M.; Španinger, E.; Košir, I.J.; Knez, Ž.; Bren, U. Hop compounds: Extraction techniques, chemical analyses, antioxidative, antimicrobial, and anticarcinogenic effects. Nutrients 2019, 11, 257 , https://doi.org/10.3390/nu11020257.

36. Maia, N.J.L.; Corrêa, J.A.F.; Rigotti, R.T.; da Silva Junior, A.A.; Luciano, F.B. Combination of natural antimicrobials for contamination control in ethanol production. World J Microbiol Biotechnol 2019, 35, 158, https://doi.org/10.1007/s11274-019-2734-6.

37. Klimek, K.; Tyśkiewicz, K.; Miazga-Karska, M.; Dębczak, A.; Rój, E.; Ginalska, G. Bioactive compounds obtained from Polish "Marynka" Hop variety using efficient two-step supercritical fluid extraction and comparison of their antibacterial, cytotoxic, and anti-proliferative activities in vitro. Molecules 2021, 26, 2366, https://doi.org/10.3390/molecules26082366.

38. Di Lodovico, S.; Menghini, L.; Ferrante, C.; Recchia, E.; Castro-Amorim, J.; Gameiro, P.; Cellini, L.; Bessa, L.J. Hop extract: An efficacious antimicrobial and anti-biofilm agent against multidrug-resistant Staphylococci strains and Cutibacterium acnes. Front Microbiol 2020, 11, 1852, https://doi.org/10.3389/fmicb.2020.01852.

39. Gottshall, R.Y.; Lucas, E.H.; Lickfeldt, A.; Roberts, J.M.. The occurrence of antibacterial substances active against Mycobacterium tuberculosis in seed plants. J Clin Invest 1949, 28, 920-923, https://doi.org/10.1172/JCI102179.

40. Langezaal, C.R.; Chandra, A.; Scheffer, J.J. Antimicrobial screening of essential oils and extracts of some Humulus lupulus L. cultivars. Pharm Weekbl Sci 1992, 14, 353-356, https://doi.org/10.1007/BF01970171.

41. Ohsugi, M.; Basnet, P.; Kadota, Sh.; Ishii, E.; Tamura, T.; Okamura, Y.; Namba, T. Antibacterial activity of traditional medicines and an active constituent lupulone from Humulus lupulus against Helicobacter pylori. J Trad Med 1997, 14, 186-191.

42. Kee, C.H. The pharmacology of Chinese herbs, 2nd ed. Boca Raton, FL, CRC Press, 1999.

43. Simpson, W.J.; Smith, A.R. Factors affecting antibacterial activity of hop compounds and their derivatives. J Appl Bacteriol 1992, 72, 327-34, https://doi.org/10.1111/j.1365-2672.1992.tb01843.x. 
44. Yasukawa, K.; Yamaguchi, A.; Arita, J.; Sakurai, S.; Ikeda, A.; Takido, M. Inhibitory effect of edible plant extracts on 12-O-etradecanoylphorbol-13-acetate-induced ear oedema in mice. Phytother Res 1993, 7,185189, https://doi.org/10.1002/ptr.2650070218.

45. Yasukawa, K.; Takeuchi, M.; Takido, M. Humulone, a bitter in the hop, inhibits tumor promotion by 12-Otetradecanoylphorbol-13-acetate in two-stage carcinogenesis in mouse skin. Oncology 1995, 52, 156-158, https://doi.org/10.1159/000227448.

46. Decuyper, L.; Kaur, G.; Versyck, C.; Blondeel, E.; Depetter, Y.; Van Hecke, K.; D'hooghe, M. Expedient synthesis of lupulones and their derivatization to 2,8-7H-dihydrochromen-7-ones. ChemistryOpen 2020, 9 , 442-444, https://doi.org/10.1002/open.202000008.

47. Weber, N.; Biehler, K.; Schwabe, K.; Haarhaus, B.; Quirin, K.W.; Frank, U.; Schempp, C.M.; Wölfle, U. hop extract acts as an antioxidant with antimicrobial effects against Propionibacterium Acnes and Staphylococcus Aureus. Molecules 2019, 24, 223, https://doi.org/10.3390/molecules24020223.

48. Oyaizu, M.; Ogihara, H.; Sekimoto, K.; Naruse, U. [Antioxidative activity of extracts from hop (Humulus lupulus L.).] Yukagaku Zasshi 1993, 42, 1003-1006, https://doi.org/10.5650/jos1956.42.1003.

49. Tagashira, M.; Watanabe, M.; Uemitsu, N. Antioxidative activity of hop bitter acids and their analogues. Biosci Biotechnol Biochem 1995, 59, 740-742. https://doi.org/10.1271/bbb.59.740.

50. Nagybákay, N.E.; Syrpas, M.; Vilimaitè, V.; Tamkute, L.; Pukalskas, A.; Venskutonis, P.R.; Kitrytė, V. Optimized supercritical $\mathrm{CO}(2)$ extraction enhances the recovery of valuable Lipophilic antioxidants and other constituents from dual-purpose hop (Humulus lupulus L.) variety Ella. Antioxidants (Basel) 2021, 10, 918, https://doi.org/10.3390/antiox10060918.

51. Vazquez-Cervantes, G.I.; Ortega, D.R.; Blanco Ayala, T.; Pérez de la Cruz, V.; Esquivel, D.F.G.; Salazar, A.; Pineda, B. Redox and anti-Inflammatory properties from Hop components in beer-related to neuroprotection. Nutrients 2021, 13, 2000, https://doi.org/10.3390/nu13062000.

52. Chrisfield, B.J.; Hopfer, H.; Elias, R.J. Impact of copper-based fungicides on the antioxidant quality of ethanolic Hop extracts. Food Chem 2021, 355, 129551, https://doi.org/10.1016/j.foodchem.2021.129551.

53. Wu, C.N.; Sun, L.C.; Chu, Y.L.; Yu, R.C.; Hsieh, C.W.; Hsu, H.Y.; Hsu, F.C.; Cheng, K.C. Bioactive compounds with antioxidative and anti-inflammatory activities of hop extracts. Food Chem 2020, 330, 127244, https://doi.org/10.1016/j.foodchem.2020.127244.

54. Vázquez Loureiro, P.; Hernández Jiménez, I.; Sendón, R.; Rodriguez-Bernaldo de Quirós, A.; BarbosaPereira, L. Determination of xanthohumol in Hops, food supplements and beers by HPLC. Foods 2019, 8, 435, https://doi.org/10.3390/foods8100435.

55. Benkherouf, A.Y.; Logrén, N.; Somborac, T.; Kortesniemi, M.; Soini, S.L.; Yang, B.; Salo-Ahen, O.M.H.; Laaksonen, O.; Uusi-Oukari, M. Hops compounds modulatory effects and 6-prenylnaringenin dual mode of action on GABA $_{\mathrm{A}}$ receptors. Eur $J$ Pharmacol 2020, 873,172962, https://doi.org/10.1016/j.ejphar.2020.172962.

56. Zanoli, P.; Rivasi, M.; Zavatti, M.; Brusiani, F.; Baraldi, M. New insight in the neuropharmacological activity of Humulus lupulus L. J Ethnopharmacol 2005, 102, 102-106, https://doi.org/10.1016/j.jep.2005.05.040.

57. Hänsel, R.; Wohlfart, R.; Coper, H. [Sedative-hypnotic compounds in the exhalation of hops, II]. Z Naturforsch C Biosci. Nov-Dec 1980, 35(11-12):1096-1097.

58. Hänsel, R·; R Wohlfart,R.; Schmidt, H. [The sedativ-hypnotic principle of hops]. Planta Med 1982, 45, 2248, https://doi.org/10.1055/s-2007-971377.

59. Koriem, K.M.M.; Gad, I.B.; Nasiry, Z.K. Protective effect of Cupressus sempervirens extract against indomethacin-induced gastric ulcer in rats. Interdiscip Toxicol 2015, 8, 25-34, https://doi.org/10.1515/intox2015-0006.

60. Cott, J. Medicinal plants and dietary supplements: sources for innovative treatments or adjuncts?. Psychopharmacol Bull 1995, 31, 131-7.

61. Sun, T.L.; Li, W.Q.; Tong, X.L.; Liu, X.Y.; Zhou, W.H. Xanthohumol attenuates isoprenaline-induced cardiac hypertrophy and fibrosis through regulating PTEN/AKT/mTOR pathway. Eur J Pharmacol 2021, 891, 173690, https://doi.org/10.1016/j.ejphar.2020.173690.

62. Tronina, T.; Popłoński, J.; Bartmańska, A. Flavonoids as phytoestrogenic components of hops and beer. Molecules 2020, 25, 4201, https://doi.org/10.3390/molecules25184201.

63. Bolton, J.L.; Dunlap, T.L.; Hajirahimkhan, A.; Mbachu, O.; Chen, S.N.; Chadwick, L.; Nikolic, D.; van Breemen, R.B.; Pauli, G.F.; Dietz, B.M. The multiple biological targets of hops and bioactive compounds. Chem Res Toxicol 2019, 32, 222-233, https://doi.org/10.1021/acs.chemrestox.8b00345. 
64. Schick, D.; Schwack, W. Detection of estrogen active compounds in Hops by planar yeast estrogen screen. $J$ Chromatogr A 2018, 1532, 191-197, https://doi.org/10.1016/j.chroma.2017.11.069.

65. Zenisek, A.; Bednar, I.J. Contribution to the identifi cation of the estrogen activity of hops. Am Perfum Arom 1960, 75, 61-62.

66. Hoelscher, M. Exposure to phytoestrogens may surpass DES exposure. Feedstuffs 1979, 51, 68-69.

67. Fenselau, C.; Talalay, P. Is oestrogenic activity present in hops?. Food Cosmet Toxicol 1973, 11, 597-603, https://doi.org/10.1016/s0015-6264(73)80330-X.

68. Kumai, A.; Asakai, R.; Sassa, S.; Okamoto, R.; Hayakawa, A. [Extraction of biologically active substances from hop.] Nippon Naibunpi Gakkai Zasshi 1984, 60, 1202-1213, https://doi.org/10.1507/endocrine1927.60.10_1202.

69. Milligan, S.R.; Kalita, J. C.; Heyerick, A.; Rong, H.; De Cooman, I.; De Keukeleire, D. Identification of a potent phytoestrogen in hops (Humulus lupulus L.) and beer. J Clin Endocrinol Metab 1999, 84, 2249-52, https://doi.org/10.1210/jcem.84.6.5887.

70. Liu, J.; Burdette, J.E.; Xu, H.; Gu, C.; van Breemen, R.B.; Bhat, K.P.; Booth, N.; Constantinou, A.I.; Pezzuto, J.M.; Fong, H.H.; Farnsworth, N.R.; Bolton, J.L. Evaluation of estrogenic activity of plant extracts for the potential treatment of menopausal symptoms. J Agric Food Chem 2001, 49, 2472-9, https://doi.org/10.1021/jf0014157.

71. Calvo-Castro, L.A.; Burkard, M.; Sus, N.; Scheubeck, G.; Leischner, C.; Lauer, U.M.; Bosy-Westphal, A.; Hund, V.; Busch, C.; Venturelli, S.; Frank, J. The oral bioavailability of 8-prenylnaringenin from Hops (Humulus Lupulus L.) in healthy women and men is significantly higher than that of its positional isomer 6prenylnaringenin in a randomized crossover trial. Mol Nutr Food Res 2018, 62, e1700838, https://doi.org/10.1002/mnfr.201700838.

72. Štulíková, K.; Karabín, M.; Nešpor, J.; Dostálek, P. Therapeutic perspectives of 8-prenylnaringenin, a potent phytoestrogen from Hops. Molecules 2018, 23, 660, https://doi.org/10.3390/molecules23030660.

73. Lam, L.K.T.; Zheng, B.L. Effects of essential oils on glutathione $S$-transferase activity in mice. J Agric Food Chem 1991, 39, 660-662, https://doi.org/10.1021/jf00004a006.

74. Miranda, C.L.; Stevens, J.F.; Helmrich, A.; Henderson, M.C.; Rodriguez, R.J.; Yang, Y.H.; Deinzer, M.L.; Barnes, D.W.; Buhler, D.R. Antiproliferative and cytotoxic effects of prenylated flavonoids from hops (Humulus lupulus) in human cancer cell lines. Food Chem Toxicol 1999, 37, 271-85, https://doi.org/10.1016/s0278-6915(99)00019-8.

75. Henderson, M.C.; Miranda, C.L.; Stevens, J.F.; Deinzer, M.L.; Buhler, D.R. In vitro inhibition of P450 enzymes by prenylated flavonoids from hops, Humulus lupulus. Xenobiotica 2000, 30, 235-251, https://doi.org/10.1080/004982500237631.

76. Ponticelli, M.; Russo, D.; Faraone, I.; Sinisgalli, C.; Labanca, F.; Lela, L.; Milella, L. The promising ability of Humulus lupulus L. iso-alpha-acids vs. diabetes, inflammation, and metabolic syndrome: A systematic review. Molecules 2021, 26, 954, https://doi.org/10.3390/molecules26040954.

77. Kim, O.K.; Yun, J.M.; Lee, M.; Park, S.J.; Kim, D.; Oh, D.H.; Kim, H.S.; Kim, G.Y. A mixture of Humulus japonicus increases longitudinal bone growth rate in Sprague Dawley rats. Nutrients 2020, 12, 2625 , https://doi.org/10.3390/nu12092625.

78. Liu, X.; Bai, J.; Jiang, C.; Song, Z.; Zhao, Y.; Nauwynck, H.; Jiang, P. Therapeutic effect of Xanthohumol against highly pathogenic porcine reproductive and respiratory syndrome viruses. Vet Microbiol 2019, 238, 108431, https://doi.org/10.1016/j.vetmic.2019.108431.

79. Ma, S.; Zhang, R.; Li, L.; Qu, H.; Wang, J.; Yang, Q.; Guo, C.; Miao, S.; Shi, X. Xanthohumol protect cognitive performance in diabetic model rats by inhibiting protein kinase B/nuclear factor kappa-B pathway. Neuroreport 2021, 32, 651-658, https://doi.org/10.1097/WNR.0000000000001595.

80. Salviati, E.; Sommella, E.; Carrizzo, A.; Di Sarno, V.; Bertamino, A.; Venturini, E.; Vecchione, C.; Campiglia, P. Characterization of phase I and phase II metabolites of hop (Humulus lupulus L.) bitter acids: In vitro and in vivo metabolic profiling by UHPLC-Q-Orbitrap. J Pharm Biomed Anal 2021, 201, 114107, https://doi.org/10.1016/j.jpba.2021.114107.

81. Morcol, T.B.; Wysocki, K.; Sankaran, R.P.; Matthews, P.D.; Kennelly, E.J. UPLC-QTof-MS(E) metabolomics reveals changes in leaf primary and secondary metabolism of hop (Humulus lupulus L.) plants under drought stress. J Agric Food Chem 2020, 68, 14698-14708, https://doi.org/10.1021/acs.jafc.0c05987.

82. Dunkel, A.; Hofmann, T.; Di Pizio, A. In Silico Investigation of bitter hop-derived compounds and their cognate bitter taste receptors. J Agric Food Chem 2020, 68, 10414-10423, https://doi.org/10.1021/acs.jafc.9b07863. 
83. van Breemen, R.B.; Chen, L.; Tonsing-Carter, A.; Banuvar, S.; Barengolts, E.; Viana, M.; Chen, S.N.; Pauli, G.F.; Bolton, J.L. Pharmacokinetic interactions of a hop dietary supplement with drug metabolism in perimenopausal and post-menopausal women. J Agric Food Chem 2020, 68, 5212-5220, https://doi.org/10.1021/acs.jafc.0c01077.

84. Hamm, A.K.; Manter, D.K.; Kirkwood, J.S.; Wolfe, L.M.; Cox-York, K.; Weir, T.L. The effect of hops (Humulus lupulus L.) extract supplementation on weight gain, adiposity and intestinal function inovariectomized mice. Nutrients 2019, 11, 3004, https://doi.org/10.3390/nu11123004.

85. Jung, T.W.; Kim, H.C.; Shin, Y.K.; Min, H.; Cho, S.W.; Kim, Z.S.; Han, S.M.; Abd El-Aty, A.M.; Hacımüftüoğlu, A.; Jeong, J.H. Humulus japonicus stimulates thermogenesis and ameliorates oxidative stress in mouse adipocytes. J Mol Endocrinol 2019, 63, 1-9, https://doi.org/10.1530/JME-19-0010.

86. Koriem, K.M.M. Antihyperlipidemic activity of the medicinal plants among Kadazan and Dusun communities in Sabah, Malaysia: A review. Asian Pac J Trop Biomed 2014, 10, 768-779, https://doi.org/10.12980/APJTB.4.2014C1144.

87. Koriem, K.M.M. A lipidomic concept in infectious diseases. Asian Pac J Trop Biomed 2017, 7, 265-274, https://doi.org/10.1016/j.apjtb.2016.12.010.

88. Blatchford, P.A.; Parkar, S.G.; Hopkins, W.; Ingram, J.R.; Sutton, K.H. Dose-dependent alterations to in vitro human microbiota composition and butyrate inhibition by a supercritical carbon dioxide hops extract. Biomolecules 2019, 9, 390, https://doi.org/10.3390/biom9090390.

89. Gangemi, S.; Minciullo, P.L.; Miroddi, M.; Chinou, I.; Calapai, G.; Schmidt, R.J. Contact dermatitis as an adverse reaction to some topically used European herbal medicinal products - part 2: Echinacea purpureaLavandula angustifolia. Contact Dermatitis 2015, 72, 193-205, https://doi.org/10.1111/cod.12328.

90. Pradalier, A.; Campinos, C.; Trinh, C. [Systemic urticaria induced by hops]. Allerg Immunol (Paris) 2002, $34,330-332$.

91. Liu, H.; Zhang, L.; Li, G.; Gao, Z. Xanthohumol protects against Azoxymethane-induced colorectal cancer in Sprague-Dawley rats. Environ Toxicol 2020, 35, 136-144, https://doi.org/10.1002/tox.22849.

92. Koriem, K.M.M. Protective effect of natural products and hormones in colon cancer using metabolome: A physiological overview. Asian Pac J Trop Biomed 2017, 7, 957-966, https://doi.org/10.1016/j.apjtb.2017.09.002

93. Kumai, A.; Okamoto, R. Extraction of the hormonal substance from hop. Toxicol Lett 1984, 21, 203-207, https://doi.org/10.1016/0378-4274(84)90207-8.

94. Štern, A.; Furlan, V.; Novak, M.; Štampar, M.; Kolenc, Z.; Kores, K.; Filipič, M.; Bren, U.; Žegura, B. Chemoprotective effects of xanthohumol against the carcinogenic mycotoxin aflatoxin B1. Foods 2021, 10, 1331, https://doi.org/10.3390/foods10061331.

95. Girisa, S.; Saikia, Q.; Bordoloi, D.; Banik, K.; Monisha, J.; Daimary, U.D.; Verma, E.; Ahn, K.S.; Kunnumakkara, A.B. Xanthohumol from hop: Hope for cancer prevention and treatment. IUBMB Life 2021, 73, 1016-1044, https://doi.org/10.1002/iub.2522. 